\title{
Phenyl-Carbonyl Coupling Reactions Promoted by Samarium Diiodide and Hexamethylphosphoramide
}

\author{
J iann-Shyng Shiue, Mei-Huey Lin, and J im-M in Fang* \\ Department of Chemistry, National Taiwan University, Taipe 106, Taiwan, Republic of China
}

Received February $11,1997^{\otimes}$

\begin{abstract}
By mediation of samarium diiodide and hexamethylphosphorami de, benzal dehydes and acetophenones underwent self- and cross-couplings to give the products having linkages at the para-carbons of phenyl rings and the carbonyl groups. The phenyl-carbonyl coupling of 2,5-dimethoxybenzaldehyde generated a Sm(III)-enolate intermediate, which was trapped by alkyl halides in a stereospecific manner to give uncommon 1,4-dialkyl-2,5-cyclohexadiene-1-carboxaldehydes. The benzal dehydes bearing tethered carbonyl chains proceeded with intramolecular phenyl-carbonyl couplings to afford fused benzocycles.
\end{abstract}

\section{Introduction}

Samarium(II) iodide is a useful one-electron-transfer reducing agent. ${ }^{1}$ A variety of additives have been used with $\mathrm{Sml}_{2}$ to effect organic reactions. For example, ${ }^{2}$ bases like $\mathrm{KOH}$, LiOMe, and $\mathrm{LiNH}_{2}$ can be used with $\mathrm{Sml}_{2}$ in the reductions of esters, amides, and oximes. The Lewis acids $\mathrm{FeCl}_{3}, \mathrm{CoCl}_{2}$, and $\mathrm{NiCl}_{2}$ are used with $\mathrm{Sml}_{2}$ to accelerate reductions of alkynes. ${ }^{2 d, 3}$ Intramolecular halide-carbonyl and ketyl-olefin couplings are carried out by $\mathrm{Sml}_{2}$ along with $\mathrm{FeCl}_{2}, \mathrm{FeCl}_{3}, \mathrm{Fe}(\text { acac) })_{3}$, tris(dibenzoylmethido)iron(III), or $\mathrm{Cp}_{2} \mathrm{ZrCl}_{2}{ }^{4} \mathrm{~A}$ dipolar cosolvent HMPA is a general and effective additive to facilitate the above-mentioned and other reactions ${ }^{5}$ such as the reduction of halides, cleavage of carbon-sulfur bonds, deoxygenation of sulfones, and halide-olefin couplings. Other dipolar cosolvents ${ }^{6}$ such as 1,3-dimethyl-3,4,5,6-tetrahydro-2(1H)-pyrimidinone (DMPU) and tripiperidinophosphine oxide $\left(\mathrm{C}_{5} \mathrm{H}_{10} \mathrm{~N}\right)_{3} \mathrm{PO}$ are occasionally utilized as a substitute for HMPA.

${ }^{\otimes}$ Abstract published in Advance ACS Abstracts, J uly 1, 1997.

(1) For leading reviews, see: (a) Natale, N, R. Org. Prep. Proc. Int. 1983, 15, 387. (b) Kagan, H. B.; Namy, J. L. Tetrahedron 1986, 42, 6573. (c) Kagan, H. B. Inorg. Chim. Acta 1987, 140, 3. (d) Kagan, H. B. New J . Chem. 1990, 14, 453. (e) I nanaga, J . Rev. Heteroatom. Chem. 1990, 3, 75. (f) Molander, G. A. In Comprehensive Organic Synthesis; Trost, B. M., Fleming, I., Eds.; Pergamon: Oxford, 1991; p 251. (g) Soderquist, J. A. Aldrichim. Acta 1991, 24, 15. (h) Molander, G. A. Chem. Rev. 1992, 92, 29. (i) Brandukova, N. E.; Vygodskii, Y. S.; Vinogradova, S. V. Russ. Chem. Rev. 1994, 63, 345. (j) Encyclopedia of Reagents for Organic Synthesis; Paquette, L. A., Ed.; Wiley: New York, 1995; Vol. 6, pp 4428-4432. (k) Molander, G. A.; Harris, C. R. Chem. Rev. 1996, 96, 307.

(2) (a) Zhang, Y.; Lin, R. Synth. Commun. 1987, 17, 329. (b) Honda, Y.; Inanaga, J .; Yamaguchi, M. J . Chem. Soc., Chem. Commun. 1989, 298. (c) Kamochi, Y.; Kudo, T. Tetrahedron Lett. 1991, 32, 3511. (d) Inanaga, J ;; Yokoyama, Y.; Baba, Y.; Yamaguchi, M. Tetrahedron Lett. 1991, 32, 5559 .

(3) (a) Suginome, H.; Yamada, S. Tetrahedron Lett. 1987, 28, 3963. (b) Lannoye, G.; Sambasivarao, K.; Wehrli, S.; Cook, J . M.; Weiss, U. j. Org. Chem. 1988, 53, 2327.

(4) (a) Molander, G. A.; Etter, J . B. J . Org. Chem. 1986, 51, 1778. (b) Otsubo, K.; I nanaga, J .; Yamaguchi, M. Tetrahedron Lett. 1986, 27, 5763. (c) Otsubo, K.; Kawamura, K.; Inanaga, J.; Yamaguchi, M. Chem. Lett. 1987, 1487. (d) Molander, G. A.; McKie, J . A. J . Org. Chem. 1991, 56, 4112.

(5) (a) Girard, P.; Namy, J . L.; Kagan, H. B. J . Am. Chem. Soc. 1980, 102, 2693. (b) Inanaga, J.; I shikawa, M.; Yamaguchi, H. Chem. Lett. 1987, 1485. (c) Hou, Z.; K obayashi, K.; Yamazaki, H. Chem. Lett. 1991, 265. (d) Walborsky, H. M.; Topolski, M. J . Org. Chem. 1992, 57, 370. (e) Molander, G. A.; McKie, J. A. J. Org. Chem. 1992, 57, 3132. (f) Wipf, P.; Venkatraman, S. J . Org. Chem. 1993, 58, 3455. (g) Enholm, E. J .; J iang, S.; Abboud, K. J . Org. Chem. 1993, 58, 4061. (h) Hojo, M.; Harada, H.; Yoshizawa, J .; Hosomi, A. J . Org. Chem. 1993, 58, 6541. (i) Mazéas, D.; Skrydstrup, T.; Doumeix, O.; Beau, J .-M. Angew. Chem., Int. Ed. Engl. 1994, 33, 1383. (j) Fukuzawa, S.-i.; Tsuchimoto, T.; Kanai, T. Chem. Lett. 1994, 1981.
Benzaldehydes are reduced with $\mathrm{Sml}_{2}$ in THF to give the corresponding benzyl alcohols $\mathbf{2}$ in the presence of a protic cosolvent such as $\mathrm{MeOH}$ or $\mathrm{t}-\mathrm{BuOH} .{ }^{5 a}$ In the absence of protic solvent, aromatic al dehydes or aromatic ketones couple readily to give pinacols 3 (the hydrodimerization products) on treatment with 1 equiv of $\mathrm{Sml}_{2}$ in THF. ${ }^{7}$ If less than 1 equiv of $\mathrm{Sml}_{2}$ is employed to react with benzaldehyde, several products including benzyl alcohol, hydrobenzoin, benzoin, and benzyl benzoate are obtained. ${ }^{8}$ We reported ${ }^{9}$ previously that various benzaldehydes undergo phenyl-carbonyl couplings to give the dimerization products, such as $\mathbf{4 a}-\mathbf{g}$, by mediation of $\mathrm{Sml}_{2} / \mathrm{HMPA}$ in THF (Scheme 1). The coupling occurs at the para-carbon of benzal dehyde, differing from the metadirecting Friedel-Crafts reactions of the benzenes containing electron-withdrawing substituents. The yields of $\mathbf{4 a}-\mathbf{g}$ vary from 18 to $80 \%$ depending on substrates and reaction conditions, while significant amounts (up to 50\%) of the aldehyde substrates are often recovered. An optimal yield (80\%) of $\mathbf{4 a}$ was obtained when the reaction was conducted with ratios $\mathrm{PhCHO} / \mathrm{Sml} / \mathrm{HMPA}=1: 2: 8$. The dipolar additive HMPA appears to play a crucial role to prevent the aromatic carbonyls from reduction or pinacol coupling (see Scheme 5 for discussion of the reaction mechnism). Additives such as DMF, TMEDA, $\mathrm{N}$-methylpyrrolidinone (NMP), and $\mathrm{N}, \mathrm{N}$-dimethylacetamide (DMA) are inferior to HMPA in promoting the formation of the dimers. These additives yield black gelatinous precipitates and lower reactivity severely. Benzal dehydes bearing $\mathrm{MeO}, \mathrm{Me}$, and $\mathrm{Cl}$ substituents at either ortho- or meta-positions also undergo the phenylcarbonyl couplings at the para-carbons, giving the dimers $\mathbf{4 b}$-g. However, the phenyl-carbonyl coupling reactions

(6) (a) Fevig, T. L.; Elliott, R. L.; Curran, D. P. J . Am. Chem. Soc 1988, 110, 5064. (b) Curran, D. P.; Wolin, R. L. Synlett 1991, 317. (c) Bennett, S. M.; Larouche, D. Synlett 1991, 805. (d) Molander, G. A.; McKie, J. A. J . Org. Chem. 1991, 56, 4112.

(7) (a) Namy, J . L.; Souppe, J .; Kagan, H. B. Tetrahedron Lett. 1983 24,765 . (b) $\mathrm{SmCl}_{3}$-catalyzed electrolyses of aromatic aldehydes and ketones in DMF or NMP also give pinacols. Leonard, E.; Dunbach, E.; Perichon, J.J . Chem. Soc., Chem. Commun. 1989, 276.

(8) (a) Okaue, Y.; I sobe, T. Mem. Fac. Sci. Kyushu Univ. Ser. C 1987, 16,25 . The reaction of benzaldehyde with $\mathrm{C}_{2} \mathrm{H}_{5} \mathrm{Sml}$ also yields benzyl alcohol, hydrobenzoin, benzoin, and benzyl benzoate in a ratio of 10: 1:18:8. See: (b) Y okoo, K.; Fujiwara, Y.; Fukagawa, T.; Taniguchi, H. Polyhedron 1983, 2, 1101.

(9) (a) Shiue, J. -S.; Lin, C.-C.; Fang, J .-M. Tetrahedron Lett. 1993, 34, 335. Application to indole and thiophene systems, see: (b) Shiue, J .-S.; Fang, J .-M. J . Chem. Soc., Chem. Commun. 1993, 1277. (c) Yang, S.-M.; Fang, J.-M. J . Chem. Soc., Perkin Trans. 1 1995, 2669. 
Scheme 1
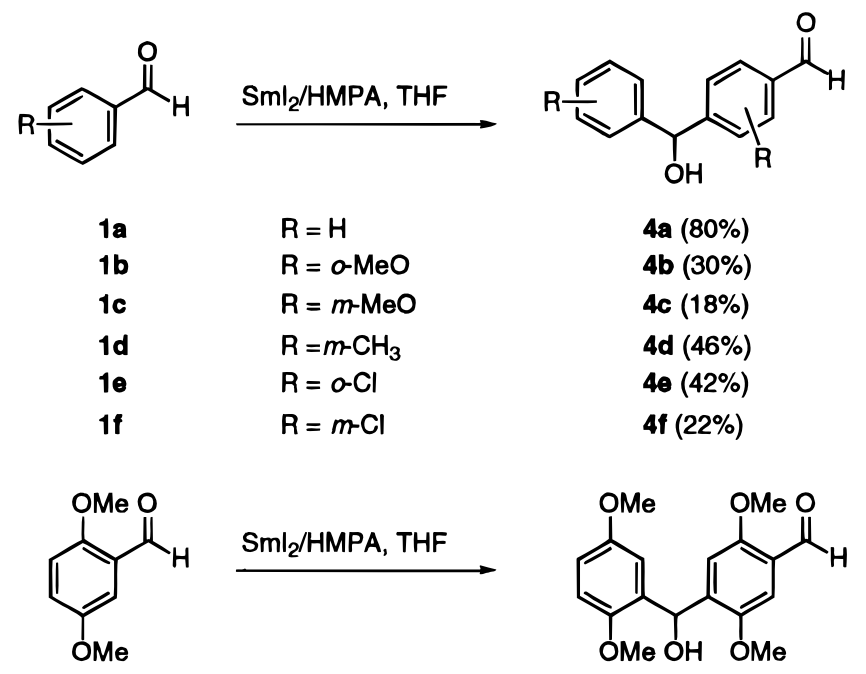

$1 \mathbf{g}$

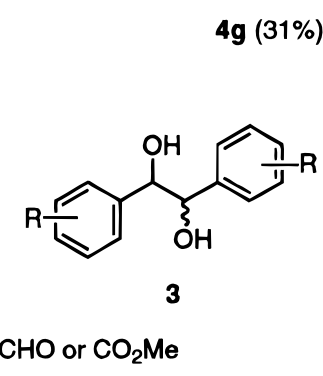

did not occur in the cases of benzaldehydes bearing electron-withdrawing substituents $\mathrm{F}, \mathrm{NO}_{2}, \mathrm{CN}, \mathrm{CHO}$, or $\mathrm{CO}_{2} \mathrm{Me}$.

In this paper, we report our further studies of this novel type of phenyl-carbonyl coupling reactions, including the dimerizations of several acetophenones and the cross-couplings between two different aromatic carbonyls. In order to gain insight into the reaction mechanism, we also examined intra- and intermolecular trappings of the samarium intermediates.

\section{Results and Discussion}

By mediation of Sml $2 / \mathrm{HMPA}$, acetophenone, its orthosubstituted analogs $\mathbf{5 b}-\mathbf{d}$, and 2,5-dimethoxyacetophenone underwent the phenyl-carbonyl couplings in THF to give the dimers $\mathbf{6 a}-\mathbf{e}$ in $\mathbf{1 0 - 3 3 \%}$ yields (Scheme 2 ). The starting acetophenones were recovered in large amounts (42-75\%). In the absence of HMPA, 2-methoxyacetophenone was reduced by $\mathrm{Sml}_{2}$ to give the benzyl alcohol $\mathbf{7 b}(35 \%)$ and the pinacol $\mathbf{8 b}$ (36\%, diastereomeric ratio 1.2:1).

Phenyl-Carbonyl Cross-Coupling. The phenylcarbonyl cross-couplings between two different aromatic carbonyl compounds were carried out in a substrateselective manner (Scheme 3). A 1:1.5 mixture of 2,5dimethoxybenzaldehyde (19) and 4-methoxybenzaldehyde (1h) was treated with $\mathrm{Sml}_{2} / \mathrm{HMPA}$ to give the crosscoupling product 9 a (34\%), along with a small amount (3\%) of dimer $\mathbf{4 g}$.

By a similar procedure, the cross-coupling product $\mathbf{9 b}$ (18\%) and the dimer $\mathbf{4 a}$ (13\%) were obtained from a 1:1 mixture of $\mathbf{1 g}$ and benzaldehyde. In this instance, 2,5dimethoxybenzaldehyde functioned as the donor substrate, whereas benzal dehyde functioned as the acceptor substrate. The other possible cross-coupling product $\mathbf{A}$,
Scheme 2

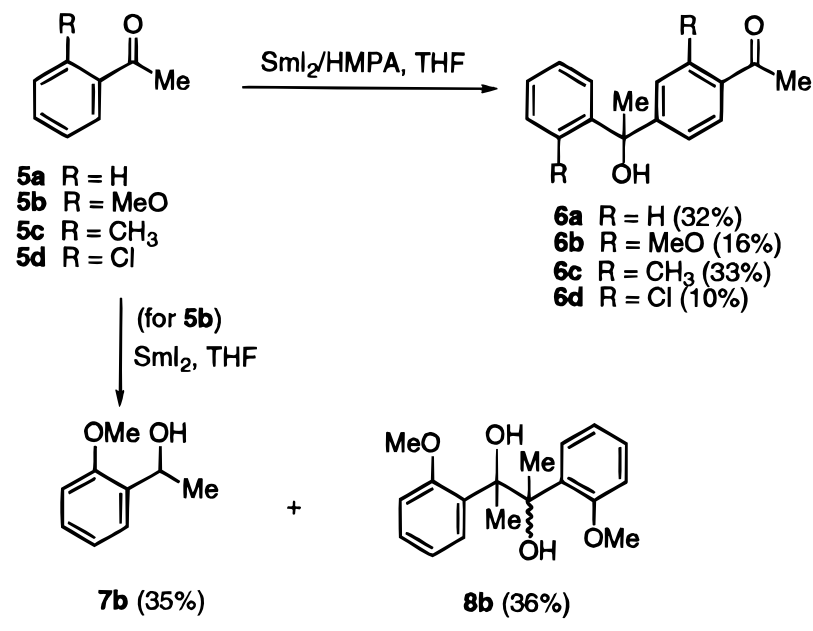

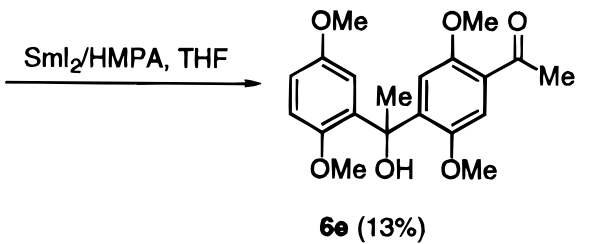

having linkage at the para-carbon of benzaldehyde and the carbonyl center of $\mathbf{1 g}$, was not observed. The reaction of acetophenone with p-methoxybenzaldehyde (1:1.5) yielded a cross-coupling product 10a (37\%) and a dimer 6a $(11 \%)$, whereas the reaction of acetophenone with benzal dehyde (1.5:1) gave a cross-coupling product 10b (27\%) and two dimers $4 \mathbf{4 a}(15 \%)$ and $\mathbf{6 a}$ (10\%). The putative cross-coupling product $\mathbf{B}$ was not found.

Intramolecular phenyl-carbonyl couplings of benzaldehydes 11a-d bearing tethered carbonyl chains were achieved (Scheme 4). Compounds 11a-c were prepared in reasonable yields by alkylations of 3-hydroxybenzaldehyde with allyl bromide, 5-bromo-1-pentene, or 6-iodo1-hexene, followed by ozonolysis of the double bonds. Compound 11d was prepared by a four-step sequence: (i) alkylation of 3-hydroxybenzaldehyde with chloroacetonitrile, (ii) protection of the aldehyde as the dimethyl acetal, (iii) addition of $\mathrm{CH}_{3} \mathrm{MgCl}$ to the cyano group, and (iv) hydrolysis of the dimethyl acetal. Treatment of 11a-d with $\mathrm{Sml}_{2} / \mathrm{HMPA}$ in THF afforded benzofuran 12a (45\%), benzoxepin 12b (82\%), benzoxocin 12c (25\%), and benzofuran $\mathbf{1 2 d}$ (88\%). Benzoxepin $\mathbf{1 2 b}$ was also obtained in a low yield (6\%) from the $\mathrm{Sml}_{2} / \mathrm{HMPA}$ promoted intramolecular coupling reaction of 4-methoxy3-(4-oxobutoxy)benzal dehyde (13). Attempts to effect the intramolecular phenyl-halide or phenyl-olefin couplings failed. Instead, 3-(3-bromopropoxy)benzal dehyde (14) was dehalogenated by $\mathrm{Sml}_{2} / \mathrm{HMPA}$ to give 3-propoxybenzaldehyde (15). On treatment with $\mathrm{Sml}_{2} / \mathrm{HMPA}$, 3-alloxybenzaldehyde (16a) and 3-cinnamoxybenzaldehyde (16b) underwent intermolecular phenyl-carbonyl couplings to give the dimers 17a (18\%) and 17b (16\%). No intramolecular cyclization product $\mathbf{C}$ was formed.

Reaction Mechanism. A possible mechanism for the formation of dimers $\mathbf{4 a}-\mathbf{g}$ and $\mathbf{6 a}-\mathbf{d}$ is proposed (Scheme 5). One-electron transfer from $\mathrm{Sml}_{2}$ to benzaldehyde would generate the ketyl radical anion $\mathbf{D}$, which might also exist as an intact organosamarium species or as the resonance forms $\mathbf{E}$ and $\mathbf{F} .{ }^{10}$ HMPA molecules are pro- 


\section{Scheme 3}

1.<smiles>COc1ccc(OC)c(C=O)c1</smiles><smiles>[R]Oc1cc(C=O)c(O[N+](=O)[O-])cc1C(O)c1ccc(P)cc1</smiles>

$9 \mathrm{a} \mathrm{R}=\mathrm{MeO}(34 \%)$ $9 b R=H(18 \%)$

2.

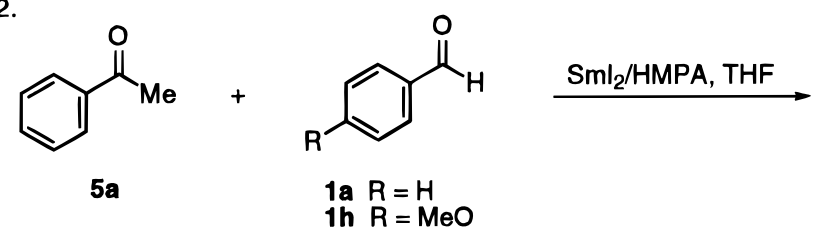<smiles>[R]c1ccc(C(O)c2ccc(C(N)=O)cc2)cc1</smiles>

$10 \mathrm{a} \mathrm{R}=\mathrm{MeO}(37 \%)$<smiles>COc1ccc(C(O)c2ccc(C=O)cc2)c(OC)c1</smiles>

A (not observed)<smiles>[M]C(O)(c1ccccc1)c1ccc(C=O)cc1</smiles>

B (not observed) posed to coordinate with samarium ion via their oxygen atoms. ${ }^{10}$ Because the ketyl- and ortho-carbons are hindered by the HMPA ligands, coupling at the para-carbon with a second molecule of benzal dehyde would be favored, forming an oxy radical $\mathbf{G}$ from $\mathbf{F}$ (path a). Further electron transfer from $\mathrm{Sml}_{2}$ to $\mathbf{G}$ would give the intermediate $\mathbf{I}$, and the subsequent protonation and oxidative aromatization, upon exposure to the air, would furnish the dimer 4a. Alternatively (path b), the radical $\mathbf{F}$ could be reduced by $\mathrm{Sml}_{2}$ to form an organosamarium $\mathbf{H}$ or its resonance species $\mathbf{H}^{\prime}$. The nucleophilic addition to benzaldehyde would give the intermediate I for the formation of 4a. As intramolecular phenyl-ol efin couplings did not occur in the reactions of alkenoxybenzaldehydes $\mathbf{1 6 a}, \mathbf{b}$, the radical process (path a) is less likely. ${ }^{11}$

(10) (a) Donoghue, J . T.; Fernandez, E.; McMillan, J . A.; Peter, D. A. J . Inorg. Nucl. Chem. 1969, 31, 1431. Reaction of benzophenone with Sml $2 /$ HMPA in THF, followed by protonation with 2,6-di-tertbutyl-4-methylphenol, gives an HMPA-ligated samarium(III) enolate of 2,5-cyclohexadienyl phenyl ketone; see: (b) Hou, Z.; Yoshimura, T.; Wakatsuki, Y. J . Am. Chem. Soc. 1994, 116, 11169.

(11) Ketyl-olefin cyclization and the subsequent alkylation may involve either radical or organosamarium intermediates; see: (a) Kawatsura, M. Matsuda, F.; Shirahama, H. J . Org. Chem. 1994, 59, 6900. (b) Molander, G. A.; McKie, J . A. J . Org. Chem. 1995, 60, 872.

\section{Scheme 4}

1.

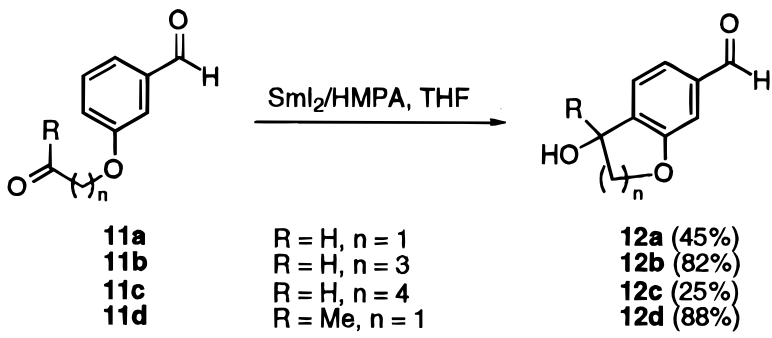

2.

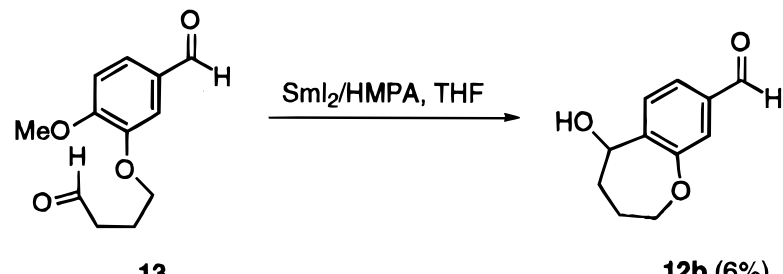

3.<smiles>CCCOc1cccc(C=O)c1</smiles>

4.<smiles>[R]C=CCOc1cccc(C(O)c2cccc(C=O)c2)c1OCC=C[R]</smiles>

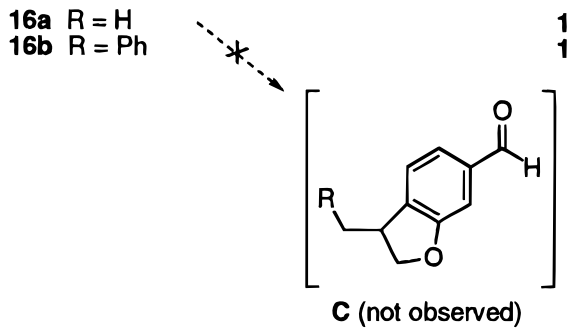

The transformations between $\mathbf{F}$ and $\mathbf{G}$ as well as that between $\mathbf{H}$ and $\mathbf{I}$ might be reversible processes. The remaining enolates $\mathbf{F}$ or $\mathbf{H}$ could be reoxidized to the starting substrate (benzaldehyde). As a consequence, dimerization of benzaldehydes or acetophenones was incomplete, and significant amounts of the starting materials were recovered. The substrate-selective formation of $\mathbf{9 b}$ and $\mathbf{1 0 b}$, but not $\mathbf{A}$ or $\mathbf{B}$, might reflect the thermodynamic preference of products or the inherent reversible nature of the phenyl-carbonyl cross couplings. Because an aromatic aldehyde group is more reactive toward $\mathrm{Sml}_{2}$ than an aliphatic carbonyl group, intramolecular phenyl-carbonyl couplings of $\mathbf{1 1 b}$ and $\mathbf{1 1 d}$ could be achieved, giving $\mathbf{1 2} \mathbf{b}$ and $\mathbf{1 2 d}$ in high yields. The reaction of 11a, giving $\mathbf{1 2 a}$ in an inferior yield, is presumably complicated by a reduction of the $\alpha$-phenoxyacetaldehyde moiety (breaking $\mathrm{C}-\mathrm{O}$ bond). ${ }^{1}$ Interestingly, (bromoalkoxy)benzaldehyde 14 underwent dehalogenation upon treatment with $\mathrm{Sml} / \mathrm{HMPA}$, giving the corresponding alkoxybenzal dehyde $\mathbf{1 5}$, with no effect 


\section{Scheme 5}<smiles>O=Cc1ccccc1</smiles>

1a

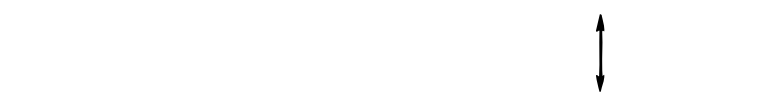

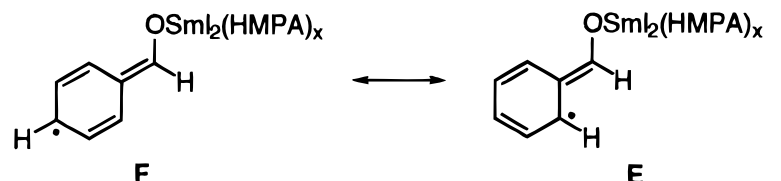

$\mathbf{F}$

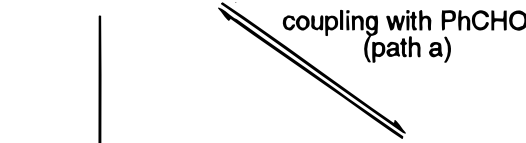

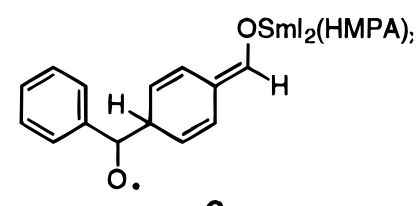

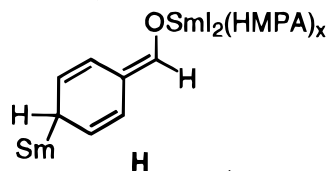

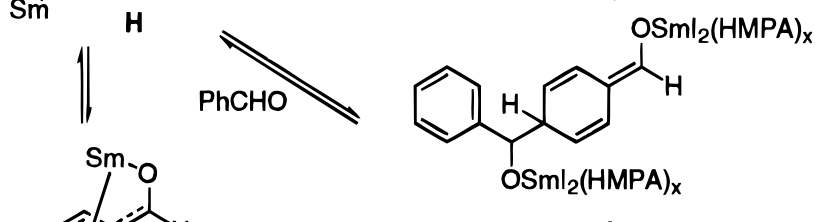<smiles>C=Cc1ccccc1</smiles><smiles>O=Cc1ccc(C(O)c2ccccc2)cc1</smiles>

on the carbonyl group. This result might be attributed to formation of an intermediate samarium enolate, similar to $\mathbf{F}$ or $\mathbf{H}$, to protect the aldehyde group from reduction.

Sequential Coupling-Alkylation. The proposed Sm(III)-enolate intermediates, ${ }^{12}$ such as I, were successfully trapped by alkylating or acylating agents (Scheme 6). Thus, 2,5-dimethoxybenzaldehyde treated with $\mathrm{Sml}_{2} / \mathrm{HMPA}$ in THF, followed by alkylation with benzyl bromide, gave a single product 18a in 84\% yield. The structure of $\mathbf{1 8 a}$ was unambiguously assigned to have the $\left(1 R^{*}, 1^{\prime} R^{*}, 4 S^{*}\right)$ configuration by X-ray analysis. The formyl proton appeared at an unusually high field $\delta$ 8.44. The ORTEP drawing of 18a al so showed that the formyl proton was oriented above the cyclohexadiene

(12) The reactions of samarium enolates are known: (a) Vougioukas, A. E.; Kagan, H. B. Tetrahedron Lett. 1987, 28, 5513. (b) Zhang, Y.; Liu, T.; Lin, R. Synth. Commun. 1988, 18, 2003. (c) Molander, G. A.; Etter, J . B.; Harring, L. S.; Thorel, P.-J .J . Am. Chem. Soc. 1991, 113, 8036. (d) Van de Weghe, P.; Collin, J . Tetrahedron Lett. 1993, 34, 3881. (e) Aoyagi, Y.; Y oshimura, M.; Tsuda, M.; Tsuchibuchi, T.; Kawamata, S.; Tateno, H.; Asano, K.; Nakamura, H.; Obokata, M.; Ohta, A.; Kodama, Y. J . Chem. Soc., Perkin Trans. 1 1995, 689. A recent report of samarium dienolate: (f) Yang, S.-M.; F ang, J .-M. Tetrahedron Lett., in press.

\section{Scheme 6}

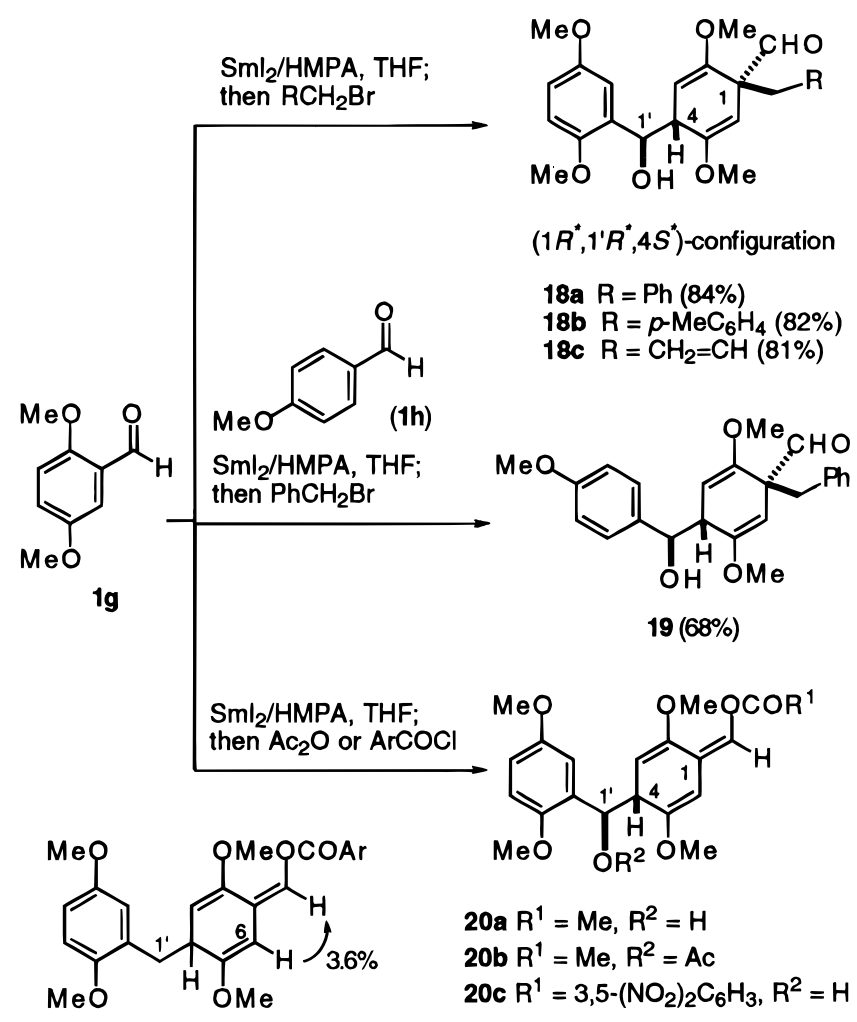

$20 \mathrm{~d} \mathrm{Ar}=3,5-\left(\mathrm{NO}_{2}\right)_{2} \mathrm{C}_{6} \mathrm{H}_{3}(51 \%)$<smiles>CC(=O)O/C=C1\C=CC([C](O)c2ccccc2)CC1</smiles>

$200 \mathrm{R}=\mathrm{H}$ $20 f R=A c$<smiles>[R]c1cc(C=O)c(OC)cc1Cc1cc(OC)ccc1OC</smiles>

21a $R=M e O(10 \%)$ 21b $R=H(6 \%)$ ring, in the shielding region of the enol ether [MeO$\mathrm{C}(2)=\mathrm{C}(3)$ ]. Similarly, trapping with 4-methylbenzyl bromide and allyl bromide occurred in a regio- and stereospecific manner to afford (cyclohexadiene)carboxaldehydes $\mathbf{1 8 b}(82 \%)$ and $\mathbf{1 8 c}(81 \%)$. A cross-coupling between 2,5-dimethoxybenzaldehyde (1g) and 4-methoxybenzaldehyde (1h), followed by alkylation with benzyl bromide, gave exclusively $\mathbf{1 9}$ (68\%). The formyl protons of $\mathbf{1 8 b}, \mathbf{1 8 c}$, and 19 also occurred at relatively high fields of $\delta 8.41,8.32$, and 8.33, respectively. Although selfcoupling of $\mathbf{1 g}$ and cross-coupling of $\mathbf{1 g}$ with $\mathbf{1 h}$ afforded dimers $\mathbf{4 g}$ (31\%) and 9a (34\%) in lower yields, trapping the intermediates with alkylating agents drives the coupling reaction through an irreversible last step, thus giving 18a-c and 19 in much higher yields. The reaction using 2,5-dimethoxybenzyl bromide as the alkylating agent proceeded differently. On treating a THF solution of $\mathbf{1 g}$ and 2,5-dimethoxybenzyl bromide with $\mathrm{Sml}_{2}$ HMPA, the reaction gave the dimer $\mathbf{4 g}(16 \%)$ and a product 21a (10\%) by direct alkylation at the para-carbon of $\mathbf{1 g}$. Treatment of 2-methoxybenzaldehyde (1b) and 2,5-dimethoxybenzyl bromide with $\mathrm{Sml}_{2} / \mathrm{HMPA}$ also afforded a small amount (6\%) of para-alkylation product $\mathbf{2 1 b}$ and the dimer $\mathbf{4 b}$ (24\%).

The self-coupling of 2,5-dimethoxybenzal dehyde, followed by O-acylation with acetic anhydride, gave the enol 
Scheme 7
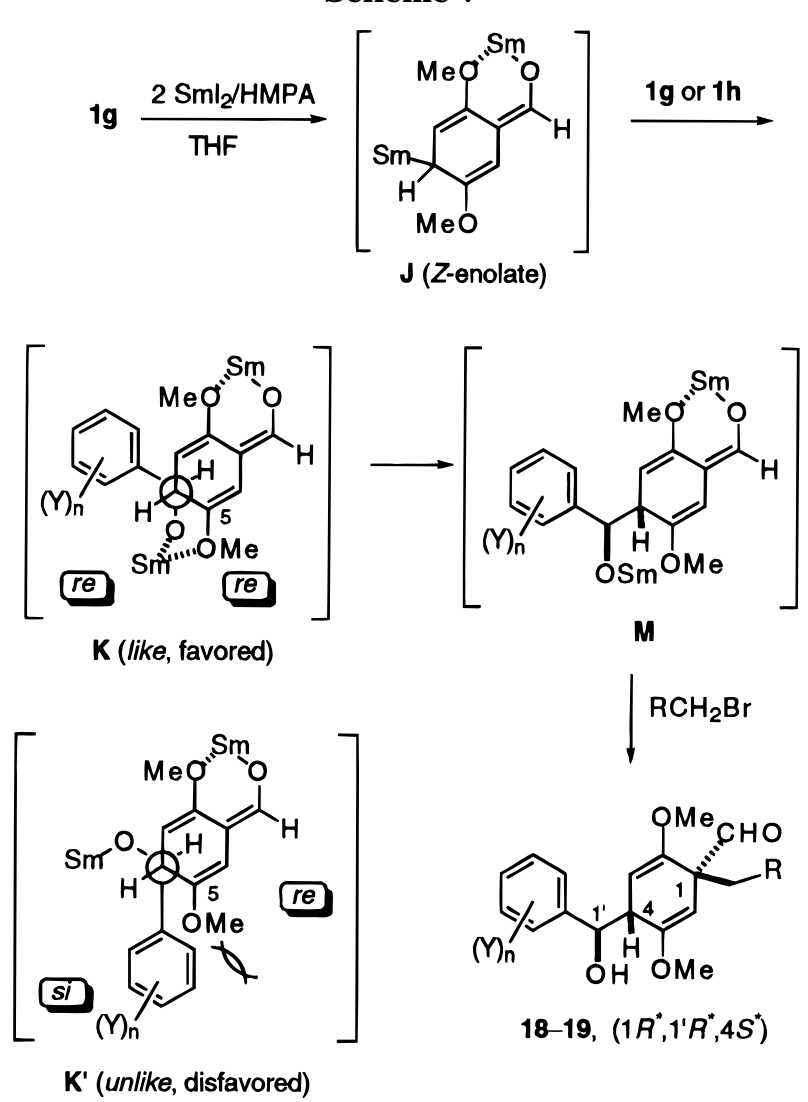

18-19, $\left(1 R^{*}, 1^{\prime} R^{*}, 4 S^{*}\right)$

acetate $\mathbf{2 0 a}$ and the diacetate $\mathbf{2 0 b}$ in $52 \%$ and $27 \%$ crude yields. These acetates were unstable and decomposed upon silica gel chromatography. The similar reaction using the acylating agent 3,5-dinitrobenzoyl chloride at $0{ }^{\circ} \mathrm{C}$ gave an enol carboxylate $20 \mathrm{c}$ ( $45 \%$ crude yield) and a 1'-deoxy compound 20d (3\%). If 2,5-dimethoxybenzaldehyde was treated with $\mathrm{Sml} / 2 / \mathrm{HMPA}$, followed by reaction with 3,5-dinitrobenzoyl chloride at $30{ }^{\circ} \mathrm{C}$ for a prolonged period (4 h), only the deoxy compound $20 \mathrm{~d}$ was obtained in $51 \%$ yield. Compound $\mathbf{2 0 c}$ decomposed on standing in $\mathrm{CDCl}_{3}$, and its structure was inferred from the ${ }^{1} \mathrm{H}$ NMR analysis. The signals at $\delta 3.63(\mathrm{H}-4), 4.69$ $\left(\mathrm{H}-1^{\prime}\right), 5.04(\mathrm{H}-3)$, and $5.81(\mathrm{H}-6)$ were characteristic. The exact mechanism for formation of $\mathbf{2 0 d}$ is unclear. An NOE study, i.e, irradiation of $\mathrm{H}-6(\delta 5.50)$, caused a $3.6 \%$ enhancement of the vinyl proton ( $\delta 7.57)$ geminal to the carboxyl group, indicating that the exo double bond of 20d had the (Z)-configuration. The reaction of benzaldehyde with $\mathrm{Sml} / 2 / \mathrm{HMPA}$, followed by acylation with acetic anhydride, also produced unstable enol acetates $20 \mathrm{e}$ and $20 \mathrm{f}$.

The resulting stereochemistry for the formation of $\mathbf{1 8}$ and 19 is interpreted as follows (Scheme 7). Reduction of 2,5-dimethoxybenzaldehyde with 2 equiv of $\mathrm{Sml}_{2}$ would give the samarium enolate $\mathbf{J}$, presumably existing as the (Z)-form as implied from the configuration of $\mathbf{2 0 d}$. The preference of (Z)-enolate might account for the chelation effect of the adjacent methoxy group. The phenylcarbonyl coupling via a liketransition state $\mathbf{K}$, giving $\mathbf{M}$, would be favored as it would be stabilized by chelation with the methoxy group at C-5. The unlike transition state $\mathbf{K}^{\prime}$ is disfavored due to the repulsion between the C-5 methoxy group and the other phenyl ring. Alkylation of $\mathbf{M}$ should occur at the less hindered face to afford the observed products 18-19.

Functional Group Elaboration. The only previous preparation of $\mathbf{4 a}$ is from the addition of $\mathrm{PhMgBr}$ to terephthaldehyde bound to a polymer. ${ }^{13}$ Our present $\mathrm{Sml} / 2 / \mathrm{HMPA}$-promoted phenyl-carbonyl coupling reaction provides a novel method to obtain various di mers of benzal dehydes and acetophenones, such as $\mathbf{4 a}-\mathbf{g}$ and $\mathbf{6 a}-\mathbf{d}$, though the yields are usually modest due to the reversible nature of these reactions. High yields were attainable in the intramolecular phenyl-carbonyl coupling reactions, as shown in the formations of tetrahydrobenzoxepin $\mathbf{1 2 b}$ and dihydrobenzofuran $\mathbf{1 2 d}$. The dimers $\mathbf{4 a}$ and $\mathbf{4 b}$ were oxidized with PDC to give diaryl ketones $\mathbf{2 2} \mathbf{a}$ and $\mathbf{2 2} \mathbf{b}$ in $80 \%$ and $85 \%$ yields, respectively.

Using our present $\mathrm{Sml} / 2 / \mathrm{HMPA}$ procedure, uncommon 1,4-dial kyl-2,5-cyclohexadiene-1-carboxaldehydes 18a-d and 19 were obtained. This dearomatization method for aromatic carbonyls is unprecedented, though partial reduction of substituted benzenes (Birch reduction) ${ }^{14}$ is well documented. In order to expand the potential of this methodology, the chemical properties of $\mathbf{1 8}$ were investigated. On treatment with $\mathrm{SOCl}_{2}$ in pyridine, 18a or 18b underwent dehydration to give an unstable alkylidenecycl ohexadiene $\mathbf{2 3} \mathbf{a}$ or $\mathbf{2 3} \mathbf{b}$, which readily decarbonylated and rearomatized to yield a 1,4-dibenzylbenzene $\mathbf{2 4 a}(\mathbf{7 1 \%})$ or $\mathbf{2 4 b}(67 \%)$. The rearomatization of 24 is most likely the driving force for the deformylation in 23. Following a similar pathway, the acetate $\mathbf{2 5 b}$ derived from 18c also reacted with DBU to furnish a small amount (5\%) of 1-allyl-4-benzylbenzene 26 . The reaction of 18a with $\mathrm{MnO}_{2}$ in $\mathrm{CH}_{2} \mathrm{Cl}_{2}\left(21^{\circ} \mathrm{C}, 5 \mathrm{~h}\right)$ did not give the desired phenone; instead, 2,5-dimethoxybenzaldehyde (19, 30\%) and 1-benzyl-2,5-dimethoxybenzene (27, 23\%) were obtained along with a recovery of $\mathbf{1 8 a}$ (47\%). The reaction of $\mathbf{1 8 a}$ with PDC afforded $\mathbf{1 g}(62 \%)$ and $27(29 \%)$ as well as diaryl ketones $28(5 \%)$ and 29 (14\%). Treatment of acetate 25a with t-BuOK in THF $\left(25^{\circ} \mathrm{C}, 18 \mathrm{~h}\right)$ afforded $\mathbf{1 g}(18 \%)$ and $\mathbf{2 7}(12 \%)$. Reduction of 18a with $\mathrm{LiAlH}_{4}$ gave the corresponding alcohol 30 (78\%), which might be converted to the p-quinodimethine 31 on treatment with $\mathrm{SOCl}_{2}$-pyridine $\left(0{ }^{\circ} \mathrm{C}, 1 \mathrm{~h}\right)$. Several diagnostic proton resonances for the quinodimethine moiety were found at $\delta 4.32,4.89,5.48$, and 5.81 in the ${ }^{1} \mathrm{H}$ NMR spectrum; however, the reaction was complicated by other intractable products and $\mathbf{3 1}$ was too unstable to be verified.

\section{Summary}

We have demonstrated the phenyl-carbonyl self- and cross-coupling reactions of various benzaldehydes and acetophenones. The method is beneficially conducted intramolecularly for the preparation of fused benzocydes. Sequential coupling-alkylations are achieved to afford high yields of uncommon 1,4-dialkyl-2,5-cyclohexadiene1-carboxaldehydes. This method can be applied to heteroaromatic systems such as indolecarboxaldehydes ${ }^{9 b}$ and thiophenecarboxaldehydes, ${ }^{9 c}$ of which aryl-carbonyl coupling products are potentially useful in the synthesis of drugs or natural products.

(13) Leznoff, C. C.; Wong, J . Y. Can. J . Chem. 1973, 51, 3756.

(14) (a) Birch, A. J .; Subba Rao, G. Adv. Org. Chem. 1972, 8, 1. (b) Kaiser, E. M. Synthesis 1972, 91. (c) Harvey, R. G. Synthesis 1980, 161. (d) Schultz, A. G.; Macielag, M. J . Org. Chem. 1986, 51, 4983. (e) Hook, J. M.; Mander, L. N. Nat. Prod. Rep. 1986, 3, 35. (f) Rabideau, P. W. Tetrahedron 1989, 45, 1599. 
<smiles>[R]c1cc(C(=O)c2ccccc2[R])ccc1C=O</smiles>

22a $R=H(80 \%)$

22b $\mathrm{R}=\mathrm{MeO}(85 \%)$<smiles>COc1ccc(OC)c(Cc2cc(OC)c(Cc3ccc(P)cc3)cc2OC)c1</smiles>

24a $\mathrm{R}=\mathrm{H}$ $24 \mathrm{~b} R=\mathrm{CH}_{3}$<smiles>C=CCc1cc(OC)c(Cc2cc(OC)ccc2OC)cc1OC</smiles>

26<smiles>COc1ccc(OC)c(C(=O)c2cc(OC)c(Cc3ccccc3)cc2OC)c1</smiles>

28<smiles>COC1=C[C@](C)(Cc2ccccc2)C(OC)=CC1C(O)c1cc(OC)ccc1OC</smiles>

30

\section{Experimental Section}

Melting points are uncorrected. ${ }^{1} \mathrm{H}$ NMR spectra were recorded at 200,300 , or $400 \mathrm{MHz} ;{ }^{13} \mathrm{C} \mathrm{NMR}$ spectra were recorded at 50,75 , or $100 \mathrm{MHz}$. Tetramethylsilane $(\delta=0$ ppm) was used as internal standard in ${ }^{1} \mathrm{H}$ NMR spectra. Mass spectra were recorded at an ionizing voltage of 70 or $20 \mathrm{eV}$. Merck silica gel 60F sheets were used for analytical thin-layer chromatography. Column chromatography was performed on $\mathrm{SiO}_{2}$ (70-230 mesh); gradients of EtOAc and n-hexane were used as eluents. High-pressure liquid chromatography was carried out on a liquid chromatograph equipped with UV (254 $\mathrm{nm}$ ) and refractive index detectors.

Typical Procedure for Phenyl-Carbonyl Coupling Reactions. Samarium metal $(0.31 \mathrm{~g}, 2 \mathrm{mmol})$ and 1,2diiodoethane $(0.38 \mathrm{~g}, 1.35 \mathrm{mmol})$ in anhydrous THF $(20 \mathrm{~mL})$ were stirred at room temperature $\left(27^{\circ} \mathrm{C}\right)$ under an atmosphere of argon for $1 \mathrm{~h}$ to give a dark blue solution. HMPA (1.4 mL, $8 \mathrm{mmol}$ ) was added, after $5 \mathrm{~min}$ the resulting dark blue solution was cooled to $0{ }^{\circ} \mathrm{C}$ in an ice bath, and benzaldehyde (106 mg, $1 \mathrm{mmol})$ in THF (2 mL) was added dropwise over a period of $2 \mathrm{~min}$. The mixture was stirred at $0{ }^{\circ} \mathrm{C}$ for $1 \mathrm{~h}$ and warmed to room temperature over a period of $0.5-2 \mathrm{~h}$. The serum cap was removed, and the reaction mixture was exposed to air to furnish the final steps of protonation and oxidative aromatization. The mixture was filtered, the filtrate was concentrated under reduced pressure, and the residue was chromatographed on a silica gel column by elution with EtOAc hexane (2:8) to give 4-( $\alpha$-hydroxybenzyl)benzaldehyde ${ }^{13}$ (4a, $81 \mathrm{mg}, 80 \%)$ : oil; TLC (EtOAc/hexane (15:85)) $\mathrm{R}_{\mathrm{f}}=0.15$; IR (neat) $3425,1689 \mathrm{~cm}^{-1} ;{ }^{1} \mathrm{H}$ NMR $\left(\mathrm{CDCl}_{3}\right) \delta 2.45(1 \mathrm{H}, \mathrm{d}, \mathrm{J}=$ $1.9 \mathrm{~Hz}, \mathrm{OH}), 5.90(1 \mathrm{H}, \mathrm{d}, \mathrm{J}=1.9 \mathrm{~Hz}), 7.26-7.37(5 \mathrm{H}, \mathrm{m})$, $7.57(2 \mathrm{H}, \mathrm{d}, \mathrm{J}=8.2 \mathrm{~Hz}), 7.85(2 \mathrm{H}, \mathrm{d}, \mathrm{J}=8.2 \mathrm{~Hz}), 9.98(1 \mathrm{H}$, s); ${ }^{13} \mathrm{C} \mathrm{NMR}\left(\mathrm{CDCl}_{3}\right) \delta 75.9,126.7,126.9$ (2 C), $128.1(2 \mathrm{C})$, 128.8 (2 C), 130.0 (2 C), 135.6, 143.0, 150.4, 191.9 (d); MS m/ z (rel intensity) $212\left(30, \mathrm{M}^{+}\right), 105$ (100).

Typical Procedure for Sequential Coupling-Alkylation. The $\mathrm{Sml}_{2}(2 \mathrm{mmol})$ solution in HMPA $(1.4 \mathrm{~mL})$ and THF $(20 \mathrm{~mL}$ ) was prepared by a procedure described for $\mathbf{4 a}$. A sol ution of 2,5-dimethoxybenzaldehyde $(1 \mathrm{mmol})$ in THF (1 $\mathrm{mL}$ ) was added dropwise over a period of $1 \mathrm{~min}$ at $0{ }^{\circ} \mathrm{C}$. The light violet solution was stirred for $10 \mathrm{~min}$, after which a solution of benzyl bromide $(0.25 \mathrm{~mL}, 2 \mathrm{mmol})$ in THF ( $1 \mathrm{~mL})$ was added. The light green solution was stirred at $0{ }^{\circ} \mathrm{C}$ for $30 \mathrm{~min}$ and at room temperature for $48 \mathrm{~h}$. $\mathrm{Et}_{2} \mathrm{O}(20 \mathrm{~mL})$ was then added, the precipitates were filtered off, and the filtrate was concentrated under reduced pressure. The residue was chromatographed on a silica gel column by elution with EtOAd hexane (3:7) to give 1-benzyl-2,5-dimethoxy-4-(2,5-dimethoxy$\alpha$-hydroxybenzyl)-2,5-cycl ohexadiene-1-carboxaldehyde (18a, $180 \mathrm{mg}, 84 \%)$. The $\left(1 \mathrm{R}^{*}, \mathrm{1}^{\prime} \mathrm{R} *, 4 \mathrm{~S}^{*}\right)$ configuration was assigned by X-ray diffraction analysis: solid; $\mathrm{mp} 118-119{ }^{\circ} \mathrm{C}$; TLC (EtOAc/hexane (3:7)) $R_{f}=0.26$; IR (neat) 3500, 1716, 1643 $\mathrm{cm}^{-1}$; ${ }^{1} \mathrm{H}$ NMR $\left(\mathrm{CDCl}_{3}\right) \delta 2.76(1 \mathrm{H}, \mathrm{d}, \mathrm{J}=13.5 \mathrm{~Hz}), 3.15(1 \mathrm{H}$, dd, J = 5.4, $4 \mathrm{~Hz}$ ), $3.21(1 \mathrm{H}, \mathrm{d}, \mathrm{J}=13.5 \mathrm{~Hz}), 3.46(3 \mathrm{H}, \mathrm{s})$, $3.53(3 \mathrm{H}, \mathrm{s}), 3.70(3 \mathrm{H}, \mathrm{s}), 3.72(3 \mathrm{H}, \mathrm{s}), 4.11(1 \mathrm{H}, \mathrm{s}), 4.62(1$ $\mathrm{H}, \mathrm{d}, \mathrm{J}=4 \mathrm{~Hz}), 5.10(1 \mathrm{H}, \mathrm{t}, \mathrm{J}=5.2 \mathrm{~Hz}), 6.72-6.74(3 \mathrm{H}, \mathrm{m})$, 6.98-7.03 $(2 \mathrm{H}, \mathrm{m}), 7.11-7.17(3 \mathrm{H}, \mathrm{m}), 8.44(1 \mathrm{H}, \mathrm{s}) ;{ }^{13} \mathrm{C} N \mathrm{NR}$ $\left(\mathrm{CDCl}_{3}\right) \delta 37.1,46.6,54.2,54.6,55.6,55.7,58.7,74.1,93.0$, $95.7,111.3,113.0,114.4,125.9,127.5$ (2 C), 129.4, 130.1 (2 C), 137.3, 151.1, 151.5, 153.4, 157.6, 198.8; MS m/ z (rel intensity) $424\left(1, \mathrm{M}^{+}\right), 167$ (100); HRMS calcd for $\mathrm{C}_{25} \mathrm{H}_{28} \mathrm{O}_{6}$ 424.1886, found 424.1876.

Typical Procedure for Sequential Coupling-Acylation. By a procedure similar to that for $\mathbf{1 8 a}$, a solution of 2,5-dimethoxybenzal dehyde (1 mmol) was treated with $\mathrm{Sml}_{2}$ $(2 \mathrm{mmol})$ in HMPA $(8 \mathrm{mmol})$ and THF $(20 \mathrm{~mL})$ at $0{ }^{\circ} \mathrm{C}$ for 10 min, followed by reaction with a solution of 3,5-dinitrobenzoyl chloride (460 mg, $2 \mathrm{mmol}$ ) in THF $(1 \mathrm{~mL})$ at $0{ }^{\circ} \mathrm{C}$ for $30 \mathrm{~min}$, to give [2,5-dimethoxy-4-(2,5-dimethoxy- $\alpha$-hydroxybenzyl)-2,5cycl ohexadienylidene]methyl 3,5-dinitrobenzoate (20c, $110 \mathrm{mg}$, 45\%) and [2,5-dimethoxy-4-(2,5-dimethoxybenzyl)-2,5-cyclohexadienylidene]methyl 3,5-dinitrobenzoate (20d, 7 mg, 3\%) after chromatography (silica gel, EtOAc/hexane (2:3)). If the reaction mixture was stirred at room temperature $\left(30^{\circ} \mathrm{C}\right)$ for $4 \mathrm{~h}$, after addition of 3,5-dinitrobenzoyl chloride, only $\mathbf{2 0 d}$ was obtained in $51 \%$ yield. Compound $\mathbf{2 0 c}$ decomposed on standing in $\mathrm{CDCl}_{3}$

20c: yellow oil; ${ }^{1} \mathrm{H} N M R\left(\mathrm{CDCl}_{3}\right) \delta 3.52(3 \mathrm{H}, \mathrm{s}), 3.60-3.65$ $(1 \mathrm{H}, \mathrm{m}), 3.71(3 \mathrm{H}, \mathrm{s}), 3.72(6 \mathrm{H}, \mathrm{s}), 4.69(1 \mathrm{H}, \mathrm{d}, \mathrm{J}=4.6 \mathrm{~Hz})$ $5.04(1 \mathrm{H}, \mathrm{d}, \mathrm{J}=6.0 \mathrm{~Hz}), 5.81(1 \mathrm{H}, \mathrm{s}), 6.73(2 \mathrm{H}, \mathrm{br} \mathrm{s}), 6.84(1$ $\mathrm{H}, \mathrm{d}, \mathrm{J}=2.1 \mathrm{~Hz}), 7.58(1 \mathrm{H}, \mathrm{d}, \mathrm{J}=1.7 \mathrm{~Hz}), 9.20-9.24(3 \mathrm{H}$ $\mathrm{m}) ;{ }^{13} \mathrm{C} \mathrm{NMR}\left(\mathrm{CDCl}_{3}\right) \delta 47.3,54.5,54.9,55.7,55.8,73.8,91.3$, $97.3,111.4,113.3,113.6,118.1,122.6,127.2,129.5,130.1$, $133.1,148.7,149.7,150.9,153.5,159.2$.

20d: yellow solid; $\mathrm{mp} 167-168{ }^{\circ} \mathrm{C}$; TLC (EtOAc/hexane (1: 3)) $\mathrm{R}_{\mathrm{f}}=0.23$; I $\mathrm{R}(\mathrm{KBr}) 2952,1741,1625,1548,1348 \mathrm{~cm}^{-1} ;{ }^{1} \mathrm{H}$ $\operatorname{NMR}\left(\mathrm{CDCl}_{3}\right) \delta 1.98(1 \mathrm{H}, \mathrm{d}, \mathrm{J}=10.5 \mathrm{~Hz}), 2.65(1 \mathrm{H}, \mathrm{dd}, \mathrm{J}=$ $10.5,4.4 \mathrm{~Hz}), 3.18(3 \mathrm{H}, \mathrm{s}), 3.28(1 \mathrm{H}, \mathrm{br} \mathrm{s}), 3.55(3 \mathrm{H}, \mathrm{s}), 3.68$ $(3 \mathrm{H}, \mathrm{s}), 3.79(3 \mathrm{H}, \mathrm{s}), 5.50(1 \mathrm{H}, \mathrm{d}, \mathrm{J}=1.2 \mathrm{~Hz}, \mathrm{H}-6), 5.65(1 \mathrm{H}$, $\mathrm{d}, \mathrm{J}=3.6 \mathrm{~Hz}, \mathrm{H}-3), 6.71(2 \mathrm{H}, \mathrm{d}, \mathrm{J}=1.2 \mathrm{~Hz}), 6.92(1 \mathrm{H}, \mathrm{d}, \mathrm{J}$ $=3 \mathrm{~Hz}), 7.57(1 \mathrm{H}, \mathrm{s}), 9.19-9.23(3 \mathrm{H}, \mathrm{m}) ;{ }^{13} \mathrm{C} \mathrm{NMR}\left(\mathrm{CDCl}_{3}\right)$ $\delta$ 36.2, 46.7, 49.8, 55.0, 55.9 (2 C), 80.0, 91.0, 106.7, 110.4, $112.4,112.9,122.5,125.6,127.5,128.4,129.5$ (2 C), 133.4, 148.7 (2 C), 150.6, 153.3, 159.4, 161.6; MS m/ z (rel intensity) 512 (1), 167 (100); HRMS calcd for $\mathrm{C}_{25} \mathrm{H}_{24} \mathrm{~N}_{2} \mathrm{O}_{10}$ 512.1431, found 512.1425 .

4-F ormylbenzophenone (22a). Under an atmosphere of argon, compound $\mathbf{4 a}(220 \mathrm{mg}, 1 \mathrm{mmol})$ in $\mathrm{CH}_{2} \mathrm{Cl}_{2}(15 \mathrm{~mL})$ was treated with PDC $(1 \mathrm{~g}, 2.4 \mathrm{mmol})$ in the presence of molecular sieves $(4 \AA, 3 \mathrm{~g})$ for $3 \mathrm{~h}$. The mixture was filtered, the filtrate was concentrated, and the residue was purified by column chromatography (silica gel, EtOAc/hexane (3:7)) to give 22a 
(190 mg, 80\%): solid; mp 54-55 ${ }^{\circ} \mathrm{C}$; TLC (EtOAc/hexane (2: 8)) $\mathrm{R}_{\mathrm{f}}=0.32 ; \mathrm{IR}(\mathrm{KBr}) 1695,1654 \mathrm{~cm}^{-1} ;{ }^{1} \mathrm{H} \mathrm{NMR}\left(\mathrm{CDCl}_{3}\right) \delta$ $7.43-7.60(3 \mathrm{H}, \mathrm{m}), 7.75(2 \mathrm{H}, \mathrm{d}, \mathrm{J}=7 \mathrm{~Hz}), 7.86(2 \mathrm{H}, \mathrm{d}, \mathrm{J}=$ $8 \mathrm{~Hz}), 7.95(2 \mathrm{H}, \mathrm{d}, \mathrm{J}=8 \mathrm{~Hz}), 10.07(1 \mathrm{H}, \mathrm{s}) ;{ }^{13} \mathrm{C} \mathrm{NMR}\left(\mathrm{CDCl}_{3}\right)$ $\delta 128.4$ (2 C), 129.4 (2 C), 130.0 (2 C), 130.2 (2 C), 133.0, 136.6, 138.4, 142.4, 191.5, 195.7; MS m/ z (rel intensity) $210\left(51, \mathrm{M}^{+}\right)$, 105 (100); HRMS calcd for $\mathrm{C}_{14} \mathrm{H}_{10} \mathrm{O}_{2} 210.0681$, found 210.0681 .

1,4-Dimethoxy-2-(2,5-dimethoxybenzyl)-5-(4-methylbenzyl)benzene (24b). Under an atmosphere of argon, a solution of 18b (250 mg, $0.57 \mathrm{mmol})$ in $\mathrm{CH}_{2} \mathrm{Cl}_{2}(15 \mathrm{~mL})$ was treated with pyridine $(0.08 \mathrm{~mL}, 1 \mathrm{mmol})$ and $\mathrm{SOCl}_{2}(0.05 \mathrm{~mL}$, $0.7 \mathrm{mmol}$ ) at $0{ }^{\circ} \mathrm{C}$ for $2 \mathrm{~h}$. The yellow solution was poured into water $(10 \mathrm{~mL})$ and extracted with $\mathrm{CH}_{2} \mathrm{Cl}_{2}(10 \mathrm{~mL} \times 3)$. The combined organic phase was dried $\left(\mathrm{Na}_{2} \mathrm{SO}_{4}\right)$, concentrated, and chromatographed on a silica gel column by elution with

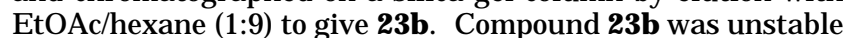
and yielded to $\mathbf{2 4 b}$ (150 $\mathrm{mg}, 67 \%$ ) on standing at room temperature for $30 \mathrm{~min}$.

23b: ${ }^{1} \mathrm{H} \mathrm{NMR}\left(\mathrm{CDCl}_{3}\right) \delta 2.56(3 \mathrm{H}, \mathrm{s}), 2.63(1 \mathrm{H}, \mathrm{d}, \mathrm{J}=13.6$ $\mathrm{Hz}), 3.10(1 \mathrm{H}, \mathrm{d}, \mathrm{J}=13.6 \mathrm{~Hz}), 3.45(3 \mathrm{H}, \mathrm{s}), 3.64(3 \mathrm{H}, \mathrm{s}), 3.67$ $(3 \mathrm{H}, \mathrm{s}), 3.72(3 \mathrm{H}, \mathrm{s}), 3.97(1 \mathrm{H}, \mathrm{s}), 5.04(1 \mathrm{H}, \mathrm{d}, \mathrm{J}=3.9 \mathrm{~Hz})$, $5.88(1 \mathrm{H}, \mathrm{d}, \mathrm{J}=3.9 \mathrm{~Hz}), 6.64-6.97(7 \mathrm{H}, \mathrm{m}), 7.87(1 \mathrm{H}, \mathrm{s})$.

24b: solid; $\mathrm{mp} 99-100{ }^{\circ} \mathrm{C}$; TLC (EtOAc/hexane (1:4)) $\mathrm{R}_{\mathrm{f}}=$ 0.81; IR (KBr) $1640 \mathrm{~cm}^{-1}$; ${ }^{1} \mathrm{H}$ NMR $\left(\mathrm{CDCl}_{3}\right) \delta 2.30(3 \mathrm{H}, \mathrm{s})$, $3.67(3 \mathrm{H}, \mathrm{s}), 3.69(6 \mathrm{H}, \mathrm{s}), 3.79(3 \mathrm{H}, \mathrm{s}), 3.89(4 \mathrm{H}, \mathrm{s}), 6.61-$ $6.80(5 \mathrm{H}, \mathrm{m}), 7.08(4 \mathrm{H}, \mathrm{br} \mathrm{s}) ;{ }^{13} \mathrm{C} \mathrm{NMR}\left(\mathrm{CDCl}_{3}\right) \delta 21.0,29.8$, 35.3, 55.5, 56.0, 56.1, 56.2, 110.8, 111.0, 113.4, 113.8, 116.7, $127.2,128.1,128.7$ (2 C), 128.9 (2 C), 130.7, 135.1, 138.0, 151.2, 151.4, 151.8, 153.4; MS m/ z (rel intensity) $392\left(100, \mathrm{M}^{+}\right)$; HRMS calcd for $\mathrm{C}_{25} \mathrm{H}_{28} \mathrm{O}_{4} 392.1988$, found 392.1985.

1-Allyl-2,5-dimethoxy-4-( $\alpha$-acetoxy-2,5-dimethoxybenzyl)-2,5-cyclohexadiene-1-carboxaldehyde (25b) and 5-Allyl-1,4-dimethoxy-2-(2,5-dimethoxybenzyl)benzene (26). Compound $18 \mathrm{c}(187 \mathrm{mg}, 0.5 \mathrm{mmol})$ was treated with $\mathrm{Ac}_{2} \mathrm{O}(1 \mathrm{~mL}, 10 \mathrm{mmol})$ in $\mathrm{Et}_{3} \mathrm{~N}(5 \mathrm{~mL})$ at room temperature for $23 \mathrm{~h}$ to give the corresponding acetate $\mathbf{2 5 b}$ (168 $\mathrm{mg}, 80 \%$ ). This sample was dissolved in THF $(15 \mathrm{~mL})$ and treated with DBU $(0.14 \mathrm{~mL}, 0.9 \mathrm{mmol}$ ) at reflux for $19 \mathrm{~h}$ to give 26 (7 mg, $5 \%)$ and other intractable compounds.

25b: oil; TLC (EtOAc/hexane (25:75)) $R_{f}=0.27$; IR (neat) 1742, $1722 \mathrm{~cm}^{-1} ;{ }^{1} \mathrm{H}$ NMR $\left(\mathrm{CDCl}_{3}\right) \delta 2.09(3 \mathrm{H}, \mathrm{s}), 2.15(1 \mathrm{H}$, dd, J = 8, $14 \mathrm{~Hz}), 2.55(1 \mathrm{H}, \mathrm{dd}, \mathrm{J}=8,14 \mathrm{~Hz}), 3.49(3 \mathrm{H}, \mathrm{s})$, $3.51(3 \mathrm{H}, \mathrm{s}), 3.58(1 \mathrm{H}, \mathrm{dd}, \mathrm{J}=4,4 \mathrm{~Hz}), 3.68(3 \mathrm{H}, \mathrm{s}), 3.70(3$ $\mathrm{H}, \mathrm{s}), 3.93(1 \mathrm{H}, \mathrm{s}), 4.84(1 \mathrm{H}, \mathrm{d}, \mathrm{J}=4 \mathrm{~Hz}), 4.90-4.99(2 \mathrm{H}$, $\mathrm{m}), 5.51(1 \mathrm{H}, \mathrm{m}), 6.51(1 \mathrm{H}, \mathrm{d}, \mathrm{J}=4 \mathrm{~Hz}), 6.68-6.80(3 \mathrm{H}, \mathrm{m})$, $7.90(1 \mathrm{H}, \mathrm{s}) ;{ }^{13} \mathrm{C} \mathrm{NMR}\left(\mathrm{CDCl}_{3}\right) \delta 21.2,35.9,44.5,54.5,54.8$, 55.8, 56.0, 57.1, 71.4, 93.0, 94.6, 111.1, 112.7, 115.5, 117.2,
$126.8,133.9,151.1,152.8,153.5,156.1,169.6,199.0 ; \mathrm{MS} \mathrm{m} / \mathrm{z}$ (rel intensity) $416\left(2, \mathrm{M}^{+}\right), 167(100)$; $\mathrm{HRMS}$ calcd for $\mathrm{C}_{23} \mathrm{H}_{28} \mathrm{O}_{7}$ 416.1835, found 416.1827.

26: oil; TLC (EtOAC/hexane (15:85)) $\mathrm{R}_{\mathrm{f}}=0.40$; IR (neat) 2949, 1501, 1217, 1047, 996, $915 \mathrm{~cm}^{-1}$; ${ }^{1} \mathrm{H} \mathrm{NMR}\left(\mathrm{CDCl}_{3}\right) \delta 3.33$ $(2 \mathrm{H}, \mathrm{d}, \mathrm{J}=6.5 \mathrm{~Hz}), 3.67(3 \mathrm{H}, \mathrm{s}), 3.68(3 \mathrm{H}, \mathrm{s}), 3.75(3 \mathrm{H}, \mathrm{s})$, $3.78(3 \mathrm{H}, \mathrm{s}), 3.89(2 \mathrm{H}, \mathrm{s}), 5.02(1 \mathrm{H}, \mathrm{dd}, \mathrm{J}=4,2 \mathrm{~Hz}), 5.07$ (1 $\mathrm{H}, \mathrm{d}, \mathrm{J}=2 \mathrm{~Hz}), 5.96(1 \mathrm{H}, \mathrm{m}), 6.60-6.69(4 \mathrm{H}, \mathrm{m}), 6.77(1 \mathrm{H}$ $\mathrm{d}, \mathrm{J}=8.7 \mathrm{~Hz}) ;{ }^{13} \mathrm{C} \mathrm{NMR}\left(\mathrm{CDCl}_{3}\right) \delta 29.8,34.2,55.6,56.0,56.2$ (2 C), 110.9, 111.1, 113.0, 113.9, 115.3, 116.7, 126.9, 127.3, 130.8, 137.2, 151.1, 151.6, 151.8, 153.5; MS m/ z (rel intensity) $328\left(100, \mathrm{M}^{+}\right)$; HRMS calcd for $\mathrm{C}_{20} \mathrm{H}_{24} \mathrm{O}_{4}$ 328.1674, Found 328.1678.

1-Benzyl-2,5-dimethoxy-1-(hydroxymethyl)-4-(2,5dimethoxy- $\alpha$-hydroxybenzyl)-2,5-cyclohexadiene (30). A solution of aldehyde $18 \mathrm{a}(300 \mathrm{mg}, 0.75 \mathrm{mmol})$ in THF $(10 \mathrm{~mL})$ was treated with $\mathrm{LiAlH}_{4}(100 \mathrm{mg}, 2.8 \mathrm{mmol})$ at room temperature for $20 \mathrm{~min}$. After addition of water, the mixture was extracted with $\mathrm{Et}_{2} \mathrm{O}(10 \mathrm{~mL} \times 2)$. The organic phase was dried $\left(\mathrm{Na}_{2} \mathrm{SO}_{4}\right)$, concentrated, and chromatographed on a silica gel column by elution with $\mathrm{EtOAc/hexane} \mathrm{(3:7)} \mathrm{to} \mathrm{give} \mathrm{the} \mathrm{al} \mathrm{cohol}$ 30 (250 mg, 78\%): solid; $\mathrm{mp} 145-146^{\circ} \mathrm{C}$; TLC (EtOAc/hexane $(45: 55)) R_{f}=0.25$; IR (KBr) 3382, 1652, 1492, 1223, $1043 \mathrm{~cm}^{-1}$; ${ }^{1} \mathrm{H}$ NMR $\left(\mathrm{CDCl}_{3}\right) \delta 2.44(1 \mathrm{H}, \mathrm{d}, \mathrm{J}=12.9 \mathrm{~Hz}), 2.97(1 \mathrm{H}, \mathrm{d}, \mathrm{J}$ $=12.9 \mathrm{~Hz}), 3.00(1 \mathrm{H}, \mathrm{dd}, \mathrm{J}=5.4,4.2 \mathrm{~Hz}), 3.20(1 \mathrm{H}, \mathrm{d}, \mathrm{J}=$ $10.2 \mathrm{~Hz}), 3.43(3 \mathrm{H}, \mathrm{s}), 3.46(3 \mathrm{H}, \mathrm{s}), 3.71(3 \mathrm{H}, \mathrm{s}), 3.73(3 \mathrm{H}, \mathrm{s})$, $3.74(1 \mathrm{H}, \mathrm{d}, \mathrm{J}=10.2 \mathrm{~Hz}), 4.31(1 \mathrm{H}, \mathrm{s}), 4.35(1 \mathrm{H}, \mathrm{d}, \mathrm{J}=4.2$ $\mathrm{Hz}), 4.37(1 \mathrm{H}, \mathrm{d}, \mathrm{J}=5.4 \mathrm{~Hz}), 6.72-6.76(2 \mathrm{H}, \mathrm{m}), 6.91(1 \mathrm{H}$, $\mathrm{d}, \mathrm{J}=2.4 \mathrm{~Hz}), 6.92-7.18(5 \mathrm{H}, \mathrm{m}) ;{ }^{13} \mathrm{C} \mathrm{NMR}\left(\mathrm{CDCl}_{3}\right) \delta 41.3$, $45.7,48.5,54.0,54.2,55.7,56.0,68.1,73.2,96.2,98.4,111.5$, $112.8,113.0,125.8,127.4$ (2 C), 130.1 (2 C), 131.4, 137.5, 150.5, 153.7, 154.1, 156.0; $\mathrm{MS} \mathrm{m} / \mathrm{z}$ (rel intensity) $426\left(1, \mathrm{M}^{+}\right), 260$ (100); HRMS calcd for $\mathrm{C}_{25} \mathrm{H}_{30} \mathrm{O}_{6} 426.2042$, found 426.2041 .

Acknowledgment. We thank the National Science Council for financial support (Grant No. NSC84-2113M002-010).

Supporting Information Available: NMR spectra of new compounds, ORTEP drawing of compound 18a, and an additional experimental procedure and data (57 pages). This material is contained in libraries on microfiche, immediately follows this article in the microfilm version of the journal, and can be ordered from the ACS, see any current masthead page for ordering information.

J 09702498 